\title{
Effect of miR-449a-mediated Notch signaling pathway on the proliferation, apoptosis and invasion of papillary thyroid carcinoma cells
}

\author{
YUJIE HOU $^{1}$, FEILING FENG ${ }^{2}$ and RONGHUA YANG ${ }^{3}$ \\ ${ }^{1}$ Department of Endocrinology, Second People's Hospital of Guilin, Guilin, \\ Guangxi Zhuang Autonomous Region 541002; ${ }^{2}$ Department of Pathophysiology, Guilin Medical University, \\ Guilin, Guangxi Zhuang Autonomous Region 541001; ${ }^{3}$ Department of Internal Medicine, \\ Guilin Medical University, Guilin, Guangxi Zhuang Autonomous Region 541002, P.R. China
}

Received June 2, 2019; Accepted November 15, 2019

DOI: $10.3892 /$ or.2019.7443

\begin{abstract}
The present study aimed to investigate the effect of miR-449a-mediated Notch signaling pathway on the proliferation, apoptosis and invasion of papillary thyroid carcinoma cells. Human papillary thyroid carcinoma cell line TPC-1 was selected, and cells were grouped and transfected: Control group (without any treatment), negative control (NC) group (transfection with NC plasmid), miR-449a mimic group (transfection with miR-449a mimic), miR-449a inhibitor group (transfection with miR-449a inhibitor), DAPT group (addition of $\gamma$-secretase inhibitor DAPT to inhibit the Notch signaling pathway), and miR-449a inhibitor + DAPT group (transfection with miR-449a inhibitor and addition of DAPT). The target relationship between miR-449a and Notch1 was detected by dual-luciferase reporter assay. qRT-PCR and western blotting were used to assess the expression of miR-449a, Notch1 and Jagged1 in cells. Cell proliferation was detected using EdU; the cell cycle and apoptosis were detected by flow cytometry; cell invasion ability was detected by Transwell assay. PCNA, MMP-2, MMP-9, Bcl-2 and Bax mRNA and protein expression were assessed by qRT-PCR and western blotting. The results revealed that miR-449a negatively regulated Notch1. Compared with the control group, there was significantly
\end{abstract}

Correspondence to: Professor Yujie Hou, Department of Endocrinology, Second People's Hospital of Guilin, Diecai Road, Diecai, Guilin, Guangxi Zhuang Autonomous Region 541002, P.R. China E-mail: houyujie2c9@163.com

Abbreviations: PTC, papillary thyroid carcinoma; miRNA, microRNA; NC, negative control; PBS, phosphate-buffered saline; PCR, polymerase chain reaction; TBST, tris-buffered saline Tween; PI, propidium iodide

Key words: miR-449a, Notch signaling pathway, papillary thyroid carcinoma, proliferation, apoptosis, invasion increased miR-449a expression in the miR-449a mimic group, and there was significantly decreased expression of Notch1, Jagged1, PCNA, MMP-2, MMP-9 and Bcl-2, increased Bax, reduced cell proliferation, increased G1-phase cell fraction, decreased S-phase cell fraction, an increased apoptosis rate, and decreased invasion ability in the miR-449a mimic group and DAPT group (all $\mathrm{P}<0.05$ ). However, the results in the miR-449a inhibitor group were the opposite of those in miR-449a mimic group (all $\mathrm{P}<0.05$ ). There was no significant difference in cell proliferation, apoptosis and invasion in the NC group and miR-449a inhibitor + DAPT group compared to the control group (all $\mathrm{P}>0.05$ ). miR-449a overexpression can inhibit Notch signaling pathway, thereby inhibiting the proliferation and invasion of papillary thyroid carcinoma cells and promoting cell apoptosis.

\section{Introduction}

Thyroid carcinoma is the leading cause of increasing morbidity and mortality of head and neck neoplasms, and $80 \%$ of patients with thyroid carcinoma have papillary thyroid carcinoma (PTC) (1). A study revealed that PTC has heterogeneous molecular characteristics and widely changeable clinical behavior during the development of the tumor as compared to other tumors in humans. Some PTCs are lethal clinically due to the tolerance to conventional radiotherapy and drug therapy in PTC (2).

The mammalian genome contains hundreds of microRNA (miRNA) and non-coding RNAs with a length of 18-25 nucleotides, regulating the expression of $30 \%$ of human genes (3), and a miRNA may function as a tumor suppressor by inhibiting the expression of an oncogene. In addition, tumor progression is promoted by reducing the expressions of certain tumor suppressors (4). Aberrant miRNA expression has been confirmed in the majority of diseases including all major cancers. However, only few human miRNAs, including miR-449 (1), miR-129-5p (5) and miR-146-5p (6), has been demonstrated to be aberrantly expressed in PTC. A study reported that miR-449 acts as a tumor suppressor by inducing cell senescence and apoptosis (7).

Notch is a multifunctional transmembrane receptor and can regulate the differentiation, development, proliferation 
and survival of normal cells or cancer cells in various cases. Notch signaling transduction consists of four Notch receptors (Notch 1,2,3 and 4) and five ligands [Delta 1,3,4 and Jagged (Jag) 1 and 2] (8). The Notch signaling pathway has been revealed to contribute to the progression of several cancers, including the proliferation, invasion and apoptosis of cancer cells $(9,10)$. Some studies have revealed that Notch1 and its ligand Jagged1 may play a key role in epithelial-mesenchymal transition and cancer stem cell regulation during the occurrence and development of a tumor, and that the alteration of Notch1 expression leads to the alteration of the Notch signaling pathway, which affects the expression of downstream Jagged1 (11-13). Many studies have revealed that the Notch signaling pathway has an impact on the proliferation, invasion and apoptosis of non-small cell lung cancer and pancreatic cancer cells, further affecting the expression of proliferation-related factor PCNA, invasion-related factors MMP-2, MMP-9 and apoptosis-related factor Bcl-2 (13-15). However, it is hard to interpret the specific mechanism of Notch signaling pathway in thyroid carcinoma. Bioinformatics prediction revealed that there is a target relationship between miR-449a and Notch1, and miR-449 plays a role in cancers by acting as a tumor suppressor (16). Therefore, it was speculated that miR-449a may suppress the Notch signaling pathway, inhibit the proliferation and invasion of PTC cells, and promote PTC cell apoptosis by targetedly downregulating Notch 1 expression.

\section{Materials and methods}

Cell culture. Human papillary thyroid carcinoma cell line TPC-1 (cat. no. JH-H1522; Shanghai Jihe Biotechnology Co. Ltd.) was cultured with RPMI-1640 medium containing $10 \%$ fetal bovine serum (FBS), $50 \mathrm{U} / \mathrm{ml}$ penicillin and $100 \mu \mathrm{g} / \mathrm{ml}$ streptomycin (all from Gibco; Thermo Fisher Scientific, Inc.) in a 5\% $\mathrm{CO}_{2}$ cell incubator (model number: Thromo3111; Thermo Fisher Scientific, Inc.) at $37^{\circ} \mathrm{C}$. The medium was renewed every day. Cells were passaged on 3-4 days. Well-grown cells in the logarithmic phase were collected for subsequent experiments.

Cell grouping and transfection. Human papillary thyroid carcinoma cell line TPC-1 in the logarithmic phase was seeded in 6 -well plates at a density of $1 \times 10^{5}$ cells/well and cultured with serum-free and double-antibody-free RPMI-1640 medium the day before transfection. Cells were divided into 6 groups: The control group (without any treatment), the negative control (NC) group (transfection with NC plasmid), the miR-449a mimic group (transfection with miR-449a mimic), the miR-449a inhibitor group (transfection with miR-449a inhibitor), the DAPT group (addition of $5 \mu \mathrm{M}$ DAPT), and the miR-449a inhibitor + DAPT group (transfection with miR-449a inhibitor and addition of DAPT). Transfection was performed strictly according to the instructions of the Lipofectamine 2000 reagent. A total of $8 \mu \mathrm{l}$ Lipofectamine 2000 (Thermo Fisher Scientific, Inc.) were mixed with $200 \mu$ phosphate-buffered saline (PBS) (Thermo Fisher Scientific, Inc.), standing for $5 \mathrm{~min} ; 50 \mathrm{nmol} / \mathrm{l} \mathrm{miR-449a}$ mimic, miR-449a inhibitor or NC plasmid dry powders (Shanghai GenePharma Co., Ltd.) were mixed with $200 \mu 1 \mathrm{PBS}$, standing for $5 \mathrm{~min}$. The two mixtures were mixed by slightly shaking, and then allowed to stand for
$20 \mathrm{~min}$ at room temperature. Then $5 \mu \mathrm{M}$ DAPT and the aforementioned mixture were added to 6-well plates and mixed gently. The medium was replaced by the medium containing $10 \%$ fetal bovine serum (Gibco; Thermo Fisher Scientific, Inc.) after $8 \mathrm{~h}$ of transfection. After $48 \mathrm{~h}$ of transfection, the cells were collected for subsequent experiments.

Dual-luciferase reporter system. The binding site of miR-449a and Notch1 was analyzed through a bioinformatics prediction website (www.targetscan.org). Then the target relationship between miR-449a and Notch1 was verified by dual-luciferase reporter system. A dual-luciferase reporter gene vector of the target gene SP1 and mutant on the binding site of miR-449a and Notch1 were constructed: PGL3-Notch1 wt and PGL3-Notch1 mut. Renilla plasmid and two reporter plasmids were co-transfected with miR-449a plasmid and NC plasmid into 293T cells (Chinese Academy of Sciences Cell Bank, Shanghai, China). A dual luciferase reporter assay was carried out $24 \mathrm{~h}$ after cell transfection. Cells were lysed with $1 \mathrm{X}$ passive lysis buffer (Promega) and centrifuged at 12,000 x g for $1 \mathrm{~min}$. The supernatant was collected. A dual-luciferase reporter kit (Promega Corp.) was used according to the instructions to assess luciferase activity. The lysed cell samples were pipetted into EP tubes. Every 10- $\mu 1$ cell sample was mixed with $100 \mu 1$ firefly luciferase working solution to assess the firefly luciferase activity and then mixed with $100 \mu 1$ Renilla luciferase working solution to assess the Renilla luciferase activity. The relative luciferase activity was calculated as follows: Firefly luciferase activity/Renilla luciferase activity.

$q R T-P C R$. Total RNA of cells collected after transfection for $48 \mathrm{~h}$ was extracted using TRIzol (cat. no. 16096020; Thermo Fisher Scientific, Inc.) and Rapid Tissue Cellular miRNA Extraction Kit (cat. no. B1802; Harbin HaiGene Biotechnology Co., Ltd.) and reverse-transcribed into cDNA using TaqMan MicroRNA Assays Reverse Transcription Primer (Thermo Scientific Scientific, Inc.). SYBR ${ }^{\circledR}$ Premix Ex Taq ${ }^{\mathrm{TM}}$ II kit (Xingzhi Biotechnology Co., Ltd., China) was used to carry out fluorescence quantitative polymerase chain reaction (PCR). The reaction solution was comprised of $25 \mu \mathrm{l}$ SYBR $^{\circledR}$ Premix Ex Taq ${ }^{\text {TM }}$ II (2X), $2 \mu$ 1 PCR forward primer, $2 \mu 1$ PCR reverse primer, $1 \mu 1$ ROX Reference Dye (50X), $4 \mu 1$

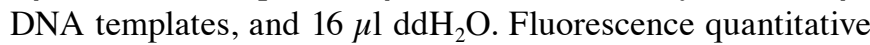
PCR was performed by ABI PRISM ${ }^{\circledR} 7300$ system (Prism ${ }^{\circledR}$ 7300; Shanghai Kunke Instruments and Equipment Co., Ltd.). Reaction conditions were as follows: Pre-denaturation at $95^{\circ} \mathrm{C}$ for $10 \mathrm{~min}, 32$ cycles of denaturation at $95^{\circ} \mathrm{C}$ for $15 \mathrm{sec}$ and annealing at $60^{\circ} \mathrm{C}$ for $30 \mathrm{sec}$ followed by extension at $72^{\circ} \mathrm{C}$ for $1 \mathrm{~min}$. The $2^{-\Delta \Delta \mathrm{Cq}}$ method was used to calculate the relative expression of the target gene (17). The following formulas were used: $\Delta \mathrm{Cq}=\mathrm{Cq}_{\text {(target gene) }}-\mathrm{Cq}_{(\mathrm{GAPDH})} ; \Delta \Delta \mathrm{Cq}=\Delta \mathrm{Cq}_{\text {(experimental }}$ group) $-\Delta \mathrm{Cq}$ (control group) . U6 was used as the internal reference of miR-449a, and for other genes GAPDH was used as the internal reference. Primers are presented in Table I.

Western blotting. After transfection for $48 \mathrm{~h}$, the cells were washed three times with precooled PBS. Total protein in cells was extracted using RIPA lysate containing PMSF (cat. no. R0010; Solarbio Life Sciences). Protein concentration was assessed by BCA kit (Thermo Fisher Scientific, Inc.), and deionized water 
Table I. Primer sequences.

\begin{tabular}{ll}
\hline Gene & \multicolumn{1}{c}{ Sequence } \\
\hline miR-449a & F: 5'-GCTGGCAGTGTATTGTTA-3' \\
& R: 5'-GTGCAGGGTCCGAGGT-3' \\
Notch1 & F: 5'-CAGCGAATCCGAOGACTATG-3' \\
& R: 5'-CAGGCGTGTTGTTCTCACAG-3' \\
Jagged1 & F: 5'-AGTCACTGGCACGGTYGTAG-3' \\
& R: 5'-TCGCTGTATCTGTCCACCTG-3' \\
PCNA & F: 5'-GTGCAGAACTTGGAAATGGAAAC-3' \\
& R: 5'-TI'GAAGAGAGTGGAGTGGCT-3' \\
MMP-2 & F: 5'-CAGGAGGAGAAGGCTGTGTT-3' \\
& R: 5'-AGGGTGCTGGCTGAGTAGAT-3' \\
MMP-9 & F: 5'-AGAACCAATCTCACCGACAGG-3' \\
& R: 5'-CGACTCTCCACGCATCTCT-3' \\
Bcl-2 & F: 5'-AACACCAGAATCAAGTGTGG-3' \\
& R: 5'-TCAGGTGGACCACAGGTGGC-3' \\
Bax & F: 5'-ACGGTITCATcCAGGATCGAGCC-3' \\
& R: 5'-AGGCGGTGAGGACTCCAGCC-3' \\
U6 & F: 5'-CTCGCTTCGGCAGCACATATACT-3' \\
& R: 5'-ACGCTTCACGAATTTGCGTGTC-3' \\
GAPDH & F: 5'-GGGTGATGCTCGTGCTGAGTATGT-3' \\
& R:5'-AAGAATGGGTGTTGCTGTTGAAGTC-3'
\end{tabular}

$F$, forward; $R$, reverse.

was used for the zero setting. The sample was mixed with loading buffer and boiled in a metal bath at $100^{\circ} \mathrm{C}$ for $10 \mathrm{~min}$. Then $50 \mu \mathrm{g}$ protein samples were added for sample application, and electrophoresis was performed for $3 \mathrm{~h}$ at a constant voltage of $70 \mathrm{~V}$. Proteins were transferred to PVDF membranes (cat. no. ISEQ00010; EMD Millipore) by wet method with a constant current of $150 \mathrm{~mA}$. The membranes were sealed with $5 \%$ skimmed milk powder at room temperature for $2 \mathrm{~h}$. The milk was discarded, and the residual milk was washed off with Tris-buffered saline Tween (TBST). The membranes were incubated with primary antibodies rabbit anti-human Notch1 (product code ab194123; 1:5,000), Jagged1 (product code ab7771; 1:500), PCNA (product code ab92552; 1:5,000), MMP-2 (product code ab37150; 1:5,000), MMP-9 (product code ab73734; 1:5,000), Bax (product code ab32503; 1:1,000), Bcl-2 (product code ab32124; 1:1,000) and GAPDH (cat. no. ab22555; 1:2,000, all from Abcam) at $4^{\circ} \mathrm{C}$ overnight. Then the membranes were washed with TBST three times, for 6 min each time. The membrane was incubated with horseradish peroxidase-labeled goat anti-rabbit IgG antibody (1:5,000, Beijing Zhongshan Biotechnology Co., Ltd.) for $2 \mathrm{~h}$. Then the membranes were washed with TBST three times, for 6 min each time, followed by immersing in Tris-buffered saline. The same volume of solution A (luminol) and B (peroxide) in an ECL fluorescent assay kit (BB-3501; BestBio, Shanghai, China) was mixed and added on the membrane drop wise. Imaging was performed by gel imager using a Bio-Rad image analysis system (Bio-Rad Laboratories, Inc.) and analyzed by ImageJ 2.0 software (National Institutes of Health). The relative protein content was calculated as follows: Gray value of the target protein band/gray value of the GAPDH band.
Cell proliferation detection by EdU. Cells in the logarithmic phase were seeded into a 24-well plate at a density of $4 \times 10^{3}$ cells/well and cultured to the normal growth phase. EdU was diluted using cell culture medium to prepare $50 \mu \mathrm{M}$ EdU solutions. EdU solutions (100 $\mu \mathrm{l})$ were added to each well, and reacted with medium for $2 \mathrm{~h}$. The medium was then discarded. Cells were washed twice with PBS, for 5 min each time. Cell fixative was supplemented with PBS containing 4\% paraformaldehyde and added into each well at $37^{\circ} \mathrm{C}$ for $30 \mathrm{~min}$. Then the reaction mixture was pipetted. PBS was supplemented with $0.5 \%$ Triton X-100 to prepare fresh penetrating agent. Fresh penetrating agent $(100 \mu \mathrm{l})$ was added to each well, followed by reaction on the shaking table at $37^{\circ} \mathrm{C}$ for $10 \mathrm{~min}$. Then cells were washed with PBS for 5 min. 1X Apollo ${ }^{\circledR}$ staining solution $(100 \mu \mathrm{l})$ was added, and the plate was coated with tin foil paper followed by reaction on a shaking table at $37^{\circ} \mathrm{C}$ for $30 \mathrm{~min}$. Then the staining solution was discarded. Fresh penetrating agent $(100 \mu \mathrm{l})$ was added to each well and reacted three times, each time for $10 \mathrm{~min}$. Then the penetrating agent was discarded. After each reaction, cells were washed with methanol twice and PBS once, successively, for $5 \mathrm{~min}$ each time. The prepared 1X Hoechst33342 dye solution was stored in a dark place. 1X Hoechst33342 dye solution $(100 \mu \mathrm{l})$ was added to each well, and the plate was coated with tin foil paper followed by reaction on the shaking table at $37^{\circ} \mathrm{C}$ for $30 \mathrm{~min}$. Then the dye solution was discarded. Each well was washed three times with $100 \mu \mathrm{l}$ PBS. Stained cells were observed under a fluorescence microscope. Five visual fields (200x) were selected randomly under an inverted microscope. EdU-stained cells (proliferative cells) and Hoechst33342 stained cells (total cells) were counted. The cell proliferation rate was calculated as follows: Cell proliferation rate $=$ number of proliferative cells/number of total cells x $100 \%$. The experiment was repeated three times.

Cell cycle and apoptosis detection by flow cytometry. After transfection for $48 \mathrm{~h}$, cells were washed with PBS three times and centrifuged at 2,200 x g for $20 \mathrm{~min}$. The supernatant was discarded. The cell concentration was adjusted to $1 \times 10^{5}$ cells/ml using PBS. Precooled $75 \%$ ethanol $(1 \mathrm{ml})$ was added to the cells and placed at $4^{\circ} \mathrm{C}$ for $1 \mathrm{~h}$. Then cells were centrifuged at 1,300 $\mathrm{x}$ g for $5 \mathrm{~min}$ and washed with PBS three times. Rnase A (120 $\mu$; Thermo Fisher Scientific, USA) was added to the cells in a dark place followed by a water bath at $37^{\circ} \mathrm{C}$ for $40 \mathrm{~min}$. Cells were dyed with $500 \mu \mathrm{l}$ propidium iodide (PI) (Sigma-Aldrich; Merck KGaA), mixed, and placed in a dark place at $4^{\circ} \mathrm{C}$ for $30 \mathrm{~min}$. Red fluorescence at an excitation wavelength of $488 \mathrm{~nm}$ was recorded by flow cytometry (BeckmanCoulter) to detect the cell cycle.

After transfection for $48 \mathrm{~h}$, cells were digested by EDTA-free trypsin (Thermo Fisher Scientific, Inc.) and collected to a flow tube. Cells were centrifuged at 2,200 $\mathrm{x}$ g for $30 \mathrm{~min}$, and the supernatant was discarded. Cells were washed with precooled PBS three times and centrifuged at 2,200 x g for $20 \mathrm{~min}$. The supernatant was discarded. HEPES buffer, Annexin-V-FITC and PI (50:1:2) were used to prepare an Annexin V-FITC/PI dye solution according to the instruction of Annexin-V-FITC apoptosis assays kit (Sigma, USA). Cells were mixed with $100 \mu \mathrm{l}$ dye solution and incubated at room temperature for $15 \mathrm{~min}$. Then cells were mixed with $1 \mathrm{ml}$ HEPES buffer (Thermo Fisher Scientific, Inc.) by shaking. 


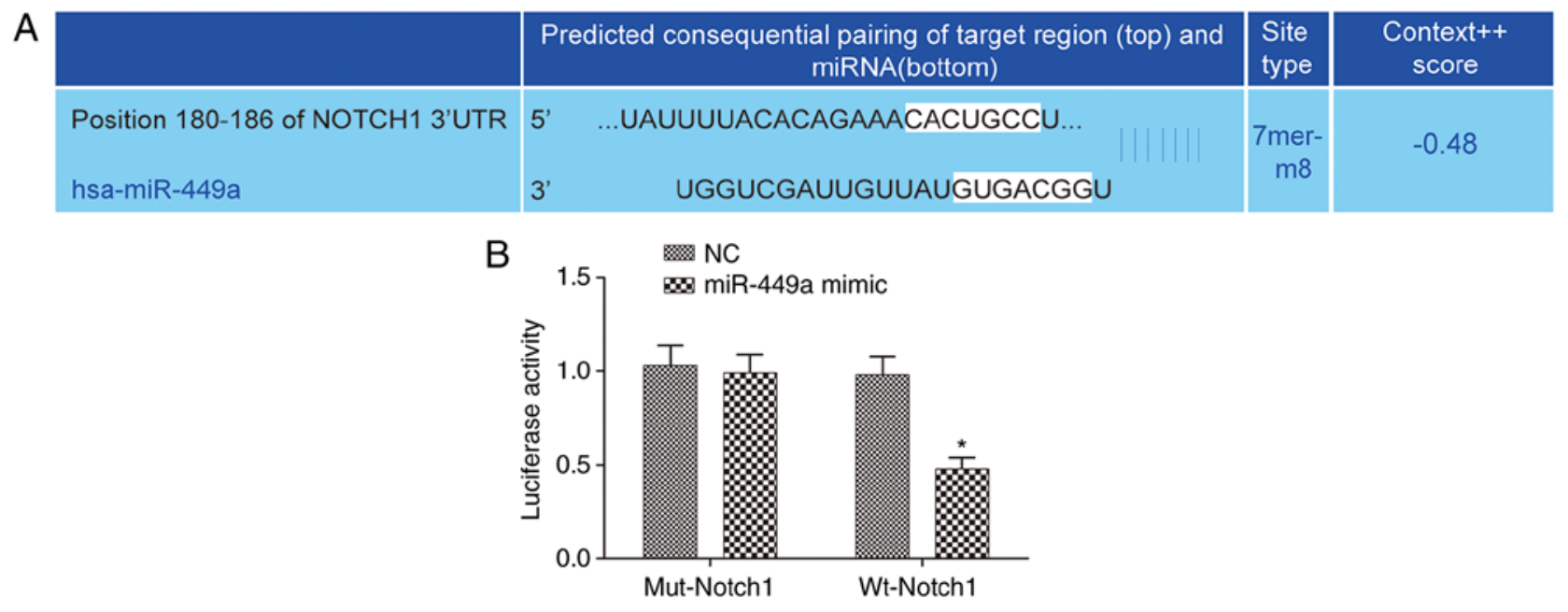

Figure 1. Negative target regulation of miR-449a on Notch1. (A) Sequence of the binding site of miR-449a and Notch1 in the 3'-UTR region. (B) Luciferase activity detection by dual-luciferase reporter assay. ${ }^{*} \mathrm{P}<0.05$, compared with the $\mathrm{NC}$ group. Mut, mutational; Wt, wild-type; $\mathrm{NC}$, negative control.

Cell apoptosis was detected at an excitation wavelength of $488 \mathrm{~nm}$ by flow cytometry.

Cell invasion detection by Transwell assay. Transwell chambers were placed into 96-well plates. The upper chamber of the Transwell chamber was coated with Matrigel diluent (1:8) and dried at room temperature. Cells were digested by trypsin and rinsed with PBS three times. Cells were re-suspended with RPMI-1640 medium at a density of $1 \times 10^{5}$ cells $/ \mathrm{ml}$. The Matrigel-coated (Qcbio Science \& Technologies Co., Ltd.) upper chamber was supplemented with $300 \mu$ cell suspension. RPMI-1640 medium (500 $\mu \mathrm{l})$ containing 10\% fetal bovine serum (Gibco; Thermo Fisher Scientific, Inc.) was added to the lower chamber. After $24 \mathrm{~h}$ of conventional culture, the Transwell chamber was removed, and unnecessary cells on the upper chamber were wiped off gently with cotton swabs. Cells were fixed with $4 \%$ paraformaldehyde (Beijing Leagene Biotechnology Co., Ltd.) for $20 \mathrm{~min}$, dyed with $0.5 \%$ crystal violet solution (Beijing Solarbio Science \& Technology Co., Ltd.) for $10 \mathrm{~min}$, and washed with PBS three times. Imaging was performed in 5 visual fields (x200) that were randomly selected under an inverted microscope. The number of cells permeating the membrane were counted.

Statistical analysis. SPSS 21.0 (IBM Corp.) software was used to analyze the data. The measurement data were expressed as the mean \pm standard deviation. Comparison among groups was performed by one-way ANOVA in conjunction with Tukey's post hoc test for pairwise comparison. A P-value of $<0.05$ was considered to be statistically significant.

\section{Results}

Negative target regulation of miR-449a on Notchl. A specific binding site of miR-449a and Notch1 was identified through analysis using bioinformatics prediction website microrna. org (http://www.microrna.org/microrna/home.do) (Fig. 1A). Results of the dual-luciferase reporter assay revealed that compared with the NC group, the luciferase activity of wild-type Notch1 was significantly reduced $(\mathrm{P}<0.05)$, and

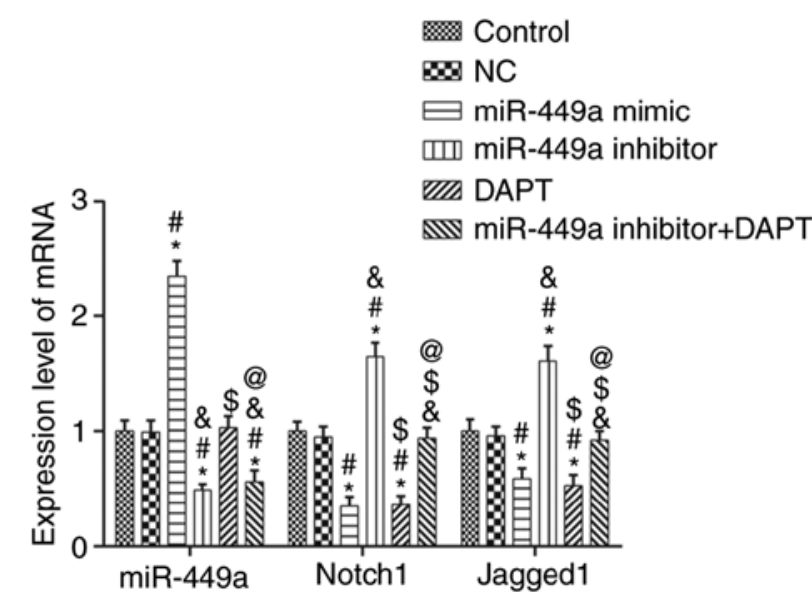

Figure 2. mRNA expression detection of miR-449a, Notch1 and Jagged1 by qRT-PCR. ${ }^{*} \mathrm{P}<0.05$, compared with the control group; ${ }^{*} \mathrm{P}<0.05$, compared with the NC group; ${ }^{\&} \mathrm{P}<0.05$, compared with the miR-449a mimic group; ${ }^{\mathrm{S}} \mathrm{P}<0.05$, compared with the miR-449a inhibitor group; ${ }^{\circledR} \mathrm{P}<0.05$, compared with the DAPT group. NC, negative control.

there was no significant difference in the luciferase activity of mutational-Notch1 in the miR-449a mimic group ( $P>0.05)$ (Fig. 1B), indicating the negative target regulation of miR-449a on Notch1.

miR-449a, Notchl and Jaggedl mRNA expression levels. The mRNA expression levels of miR-449a and Notch1, signaling pathway-related factors, were detected by qRT-PCR (Fig. 2). Compared to the control group, there was no significant difference in the expression of genes in the NC group $(\mathrm{P}>0.05)$, however, the mRNA expression of Notch1 and Jagged1 in the miR-449a mimic group and DAPT group were significantly decreased (both $\mathrm{P}<0.05$ ). In dddition, Notch1 and Jagged1 mRNA expression levels in the miR-449a inhibitor group were significantly increased (both $\mathrm{P}<0.05$ ). Compared with the miR-449a inhibitor group, Notch1 and Jagged1 mRNA expression levels in the miR-449a inhibitor + DAPT group were significantly decreased (both $\mathrm{P}<0.05$ ). miR-449a was significantly increased in miR-449a mimic group and 


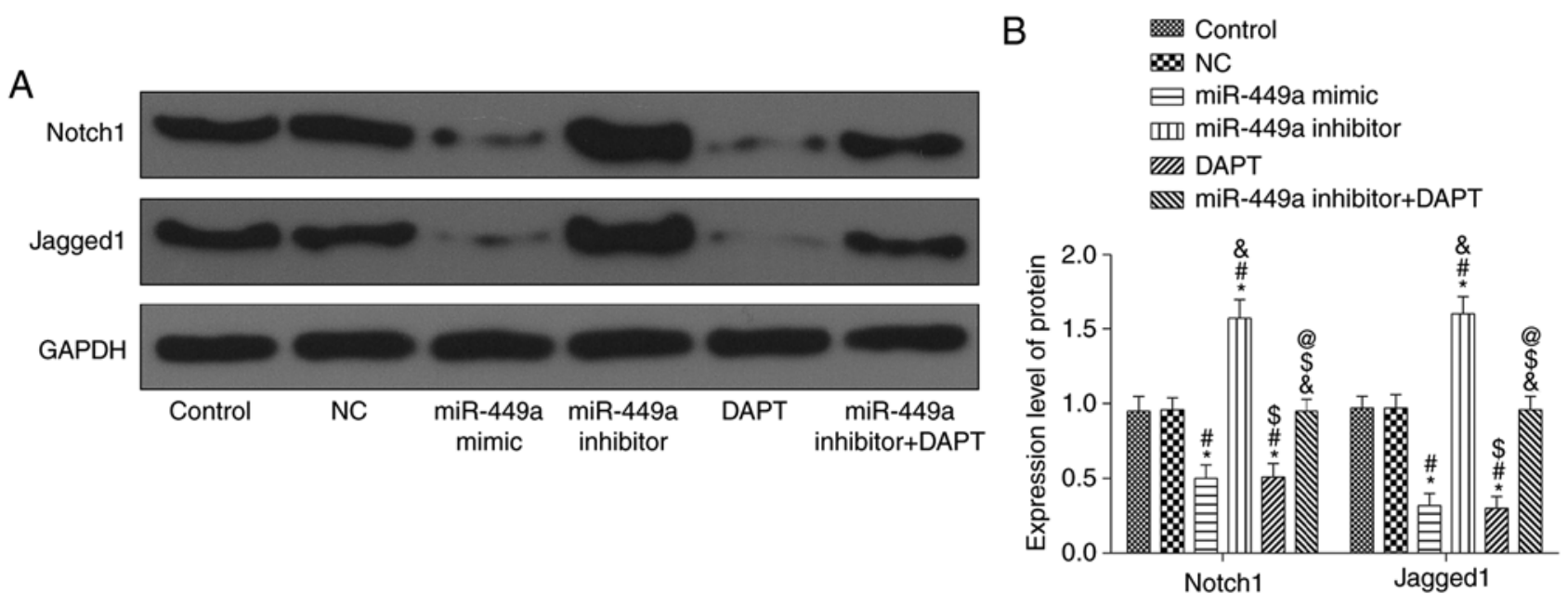

Figure 3. Notch1 and Jagged1 protein expression detection by western blotting. (A) Notch1 and Jagged1 protein bands. (B) Notch1 and Jagged1 protein expression. " $\mathrm{P}<0.05$, compared with the control group; ${ }^{\prime \mathrm{P}}<0.05$, compared with the NC group; ${ }^{\text {\& }} \mathrm{P}<0.05$, compared with the miR-449a mimic group; ${ }^{\mathrm{P}} \mathrm{P}<0.05$, compared with the miR-449a inhibitor group; ${ }^{\circledR} \mathrm{P}<0.05$, compared with the DAPT group. NC, negative control.
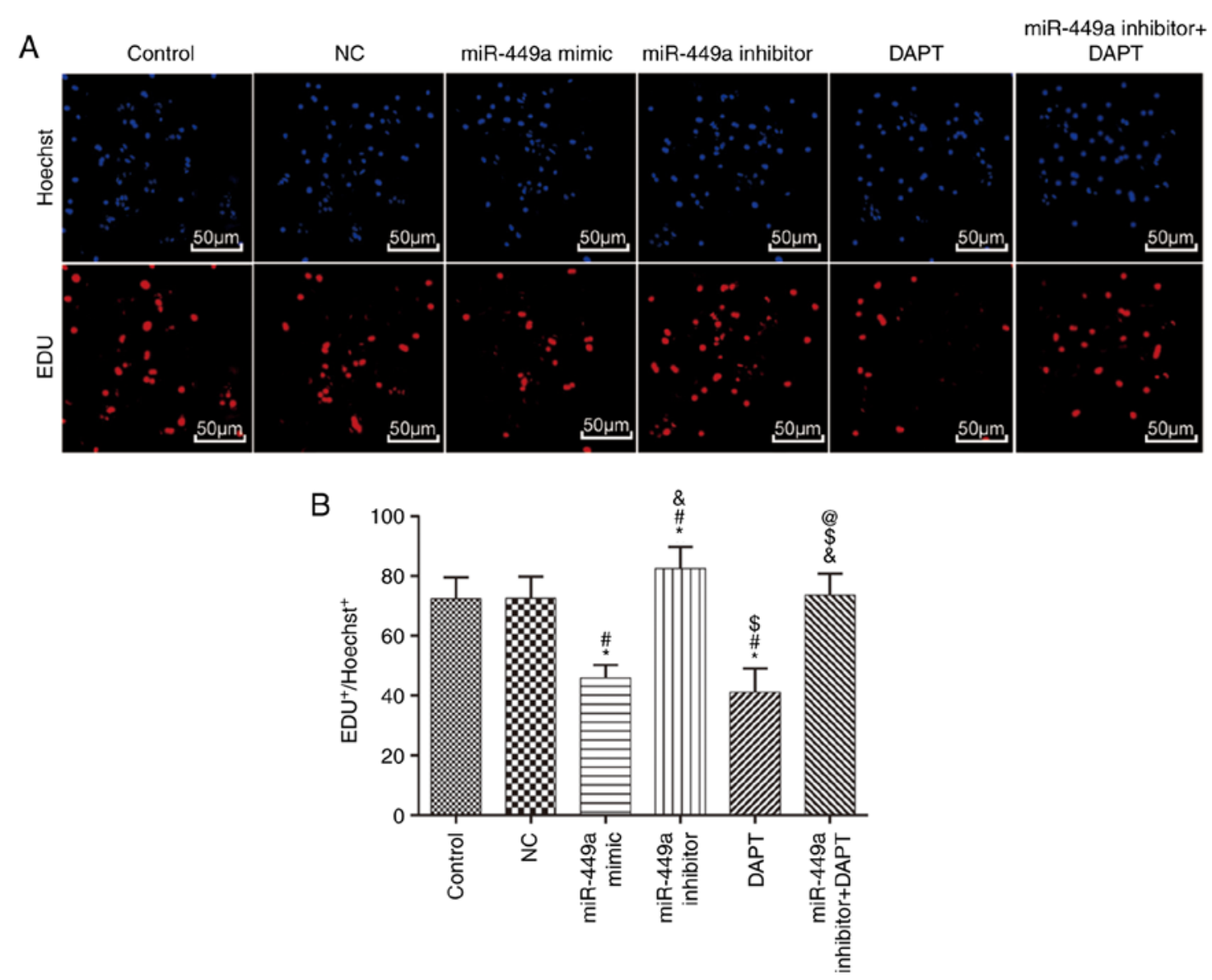

Figure 4. Cell proliferation detection by EdU. (A) EdU staining (x100). (B) Cell proliferation. ${ }^{*} \mathrm{P}<0.05$, compared with the control group; ${ }^{\#} \mathrm{P}<0.05$, compared with the NC group; ${ }^{\&} \mathrm{P}<0.05$, compared with the miR-449a mimic group; ${ }^{\$} \mathrm{P}<0.05$, compared with the miR-449a inhibitor group; ${ }^{\circledR} \mathrm{P}<0.05$, compared with the DAPT group. NC, negative control.

significantly decreased in the miR-449a inhibitor group and miR-449a inhibitor + DAPT group (all $\mathrm{P}<0.05)$.

Notchl and Jagged1 protein expression levels. Results of western blotting are presented in Fig. 3. Compared with the control group, there was no significant difference in the protein expression levels of genes in the NC group ( $\mathrm{P}>0.05)$, however, the protein expression levels of Notch1 and Jagged1 in the miR-449a mimic group and DAPT group were significantly decreased (both $\mathrm{P}<0.05$ ). In addition, Notch1 and Jagged1 protein expression levels in the miR-449a inhibitor group were significantly increased (both $\mathrm{P}<0.05$ ). Compared with 
A
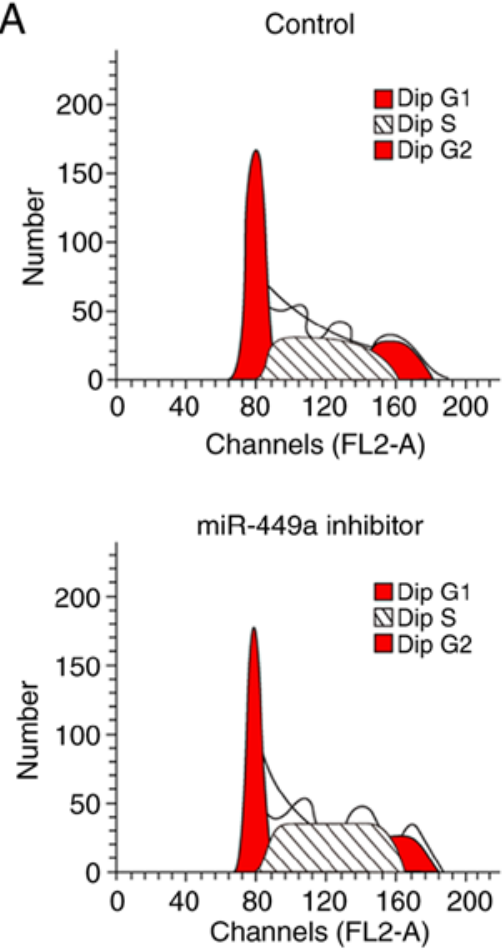

NC

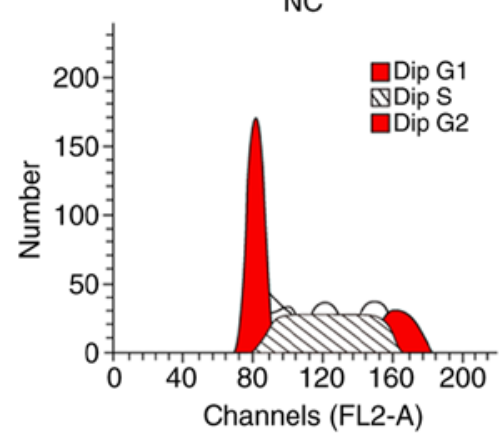

DAPT

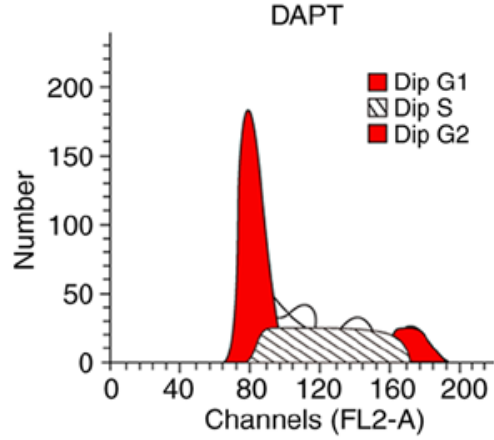

miR-449a mimic

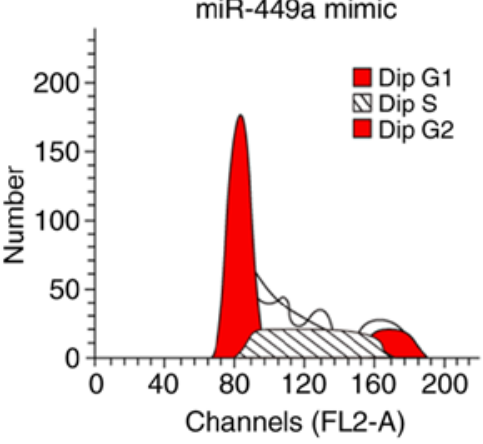

miR-449a inhibitor+DAPT

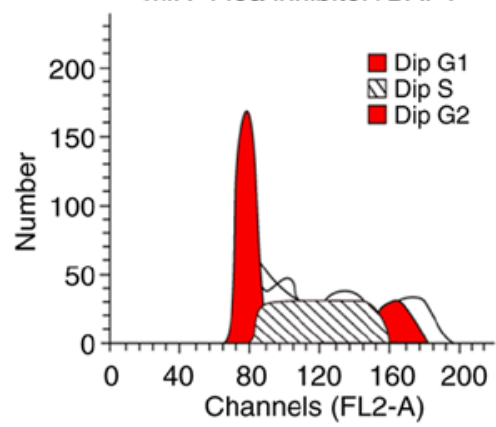

B Control $\infty$ NC $\Xi$ miR-449a mimic एس] miR-449a inhibitor שIIA DAPT miR-449a inhibitor+DAPT

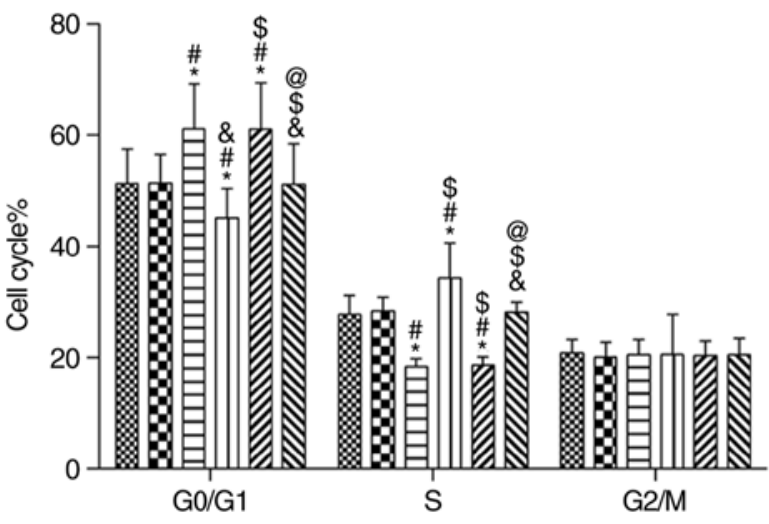

Figure 5. Cell cycle detection by flow cytometry. (A) The cell cycle. (B) Cell cycle distribution. ${ }^{*} \mathrm{P}<0.05$, compared with the control group; ${ }^{*} \mathrm{P}<0.05$, compared with the NC group; ${ }^{\&} \mathrm{P}<0.05$, compared with the miR-449a mimic group; ${ }^{\$} \mathrm{P}<0.05$, compared with the miR-449a inhibitor group; ${ }^{\circledR} \mathrm{P}<0.05$, compared with the DAPT group. NC, negative control.

the miR-449a inhibitor group, Notch1 and Jagged1 protein expression levels in the miR-449a inhibitor + DAPT group were significantly decreased (both $\mathrm{P}<0.05$ ).

Cell proliferation. Results of EdU are presented in Fig. 4. Compared with the control group, there was no significant difference in the EdU-positive cell rate in the NC group ( $P>0.05)$, however, the EdU-positive cell rate in the miR-449a mimic group and DAPT group was significantly lower (both $\mathrm{P}<0.05)$. In addition, the EdU-positive cell rate in the miR-449a inhibitor group was significantly higher $(\mathrm{P}<0.05)$. Compared with miR-449a inhibitor group, the EdU-positive cell rate in the miR-449a inhibitor + DAPT group was significantly decreased $(\mathrm{P}<0.05)$.

Cell cycle. Results of flow cytometry are presented in Fig. 5. Compared with the control group, there was no significant difference in each phase in the NC group and miR-449a inhibitor + DAPT group (both $\mathrm{P}>0.05$ ); there was a significant increase of cells in the G1 phase and a significant 
A

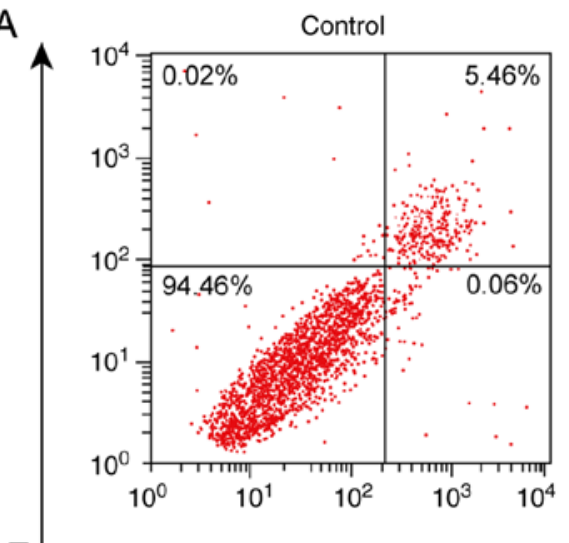

$\overline{\mathrm{a}}$

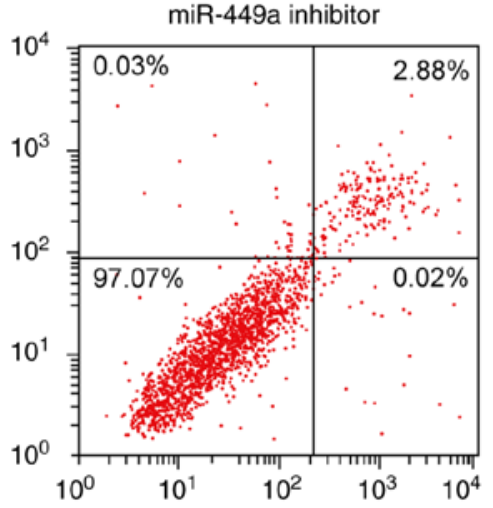

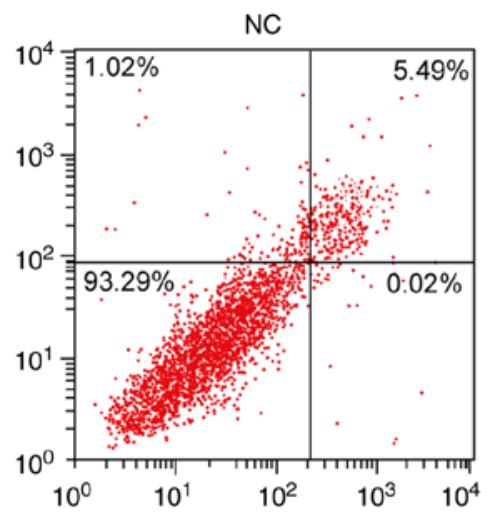
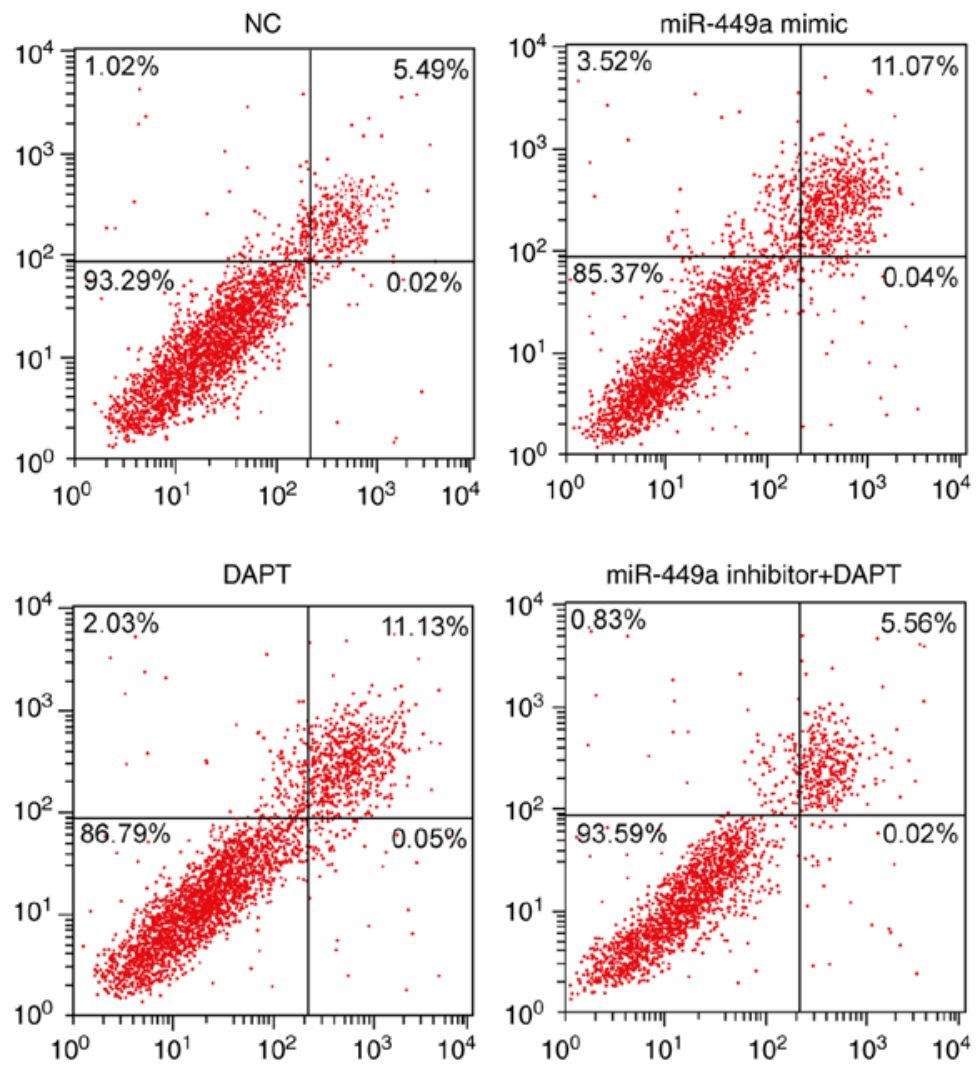

Annexin V-FITC

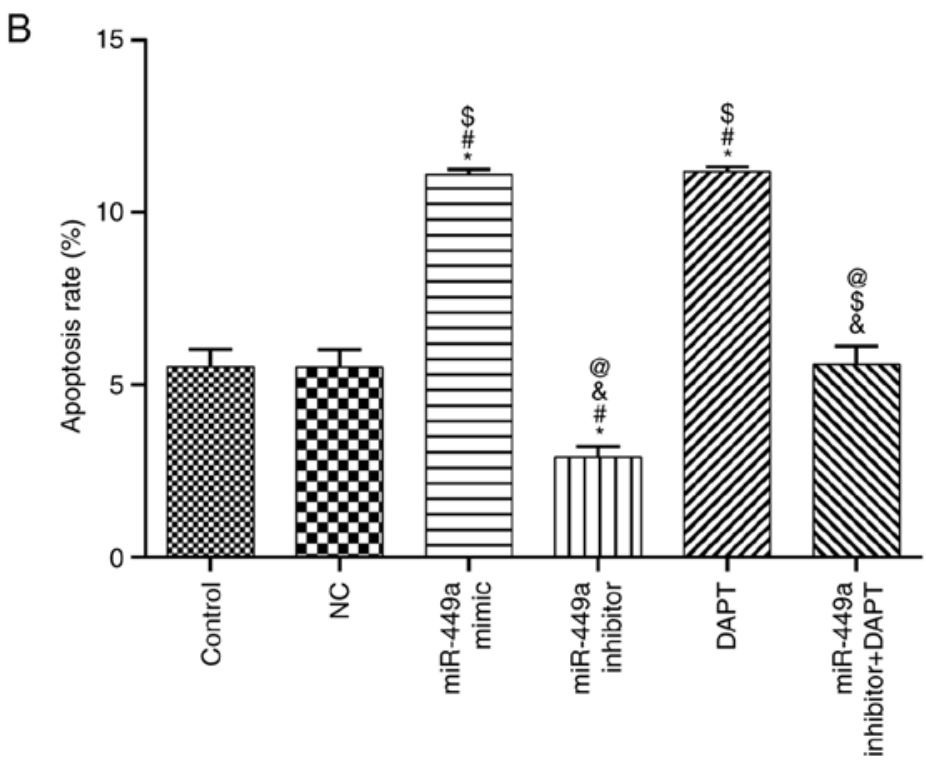

Figure 6. Apoptosis detection by flow cytometry. (A) Flow cytometric scatter plot. (B) Apoptosis rate. ${ }^{*} \mathrm{P}<0.05$, compared with the control group; ${ }^{\sharp} \mathrm{P}<0.05$, compared with the NC group; ${ }^{\circledR} \mathrm{P}<0.05$, compared with the miR-449a mimic group; ${ }^{{ }^{\mathrm{P}}} \mathrm{P}<0.05$, compared with the miR-449a inhibitor group; ${ }^{\circledR} \mathrm{P}<0.05$, compared with the DAPT group. NC, negative control; PI, propidium iodide.

decrease of cells in the $S$ phase in the miR-449a mimic group and DAPT group (both $\mathrm{P}<0.05$ ). There was also a significant decrease of cells in the G1 phase and a significant increase of cells in the $\mathrm{S}$ phase in the miR-449a inhibitor group (both $\mathrm{P}<0.05$ ). Compared with miR-449a inhibitor group, there was a significant increase of cells in the G1 phase and a significant decrease of cells in the $S$ phase in the miR-449a inhibitor + DAPT group (both $\mathrm{P}<0.05$ ). There was no significant difference in cells in the G2 phase among groups $(\mathrm{P}>0.05)$.

Apoptosis. Apoptosis was detected by flow cytometry (Fig. 6). Compared with the control group, there was no significant difference in apoptosis in the NC group and miR-449a inhibitor + DAPT group (both $\mathrm{P}>0.05$ ), however, apoptosis was significantly increased in the miR-449a mimic group and 


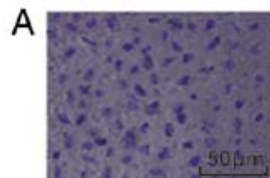

Control
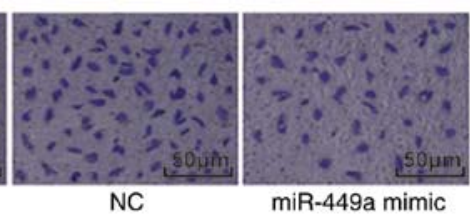

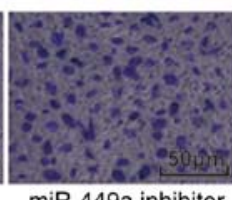

miR-449a inhibitor

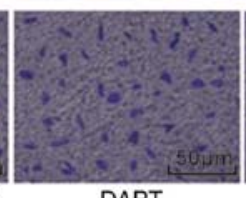

DAPT

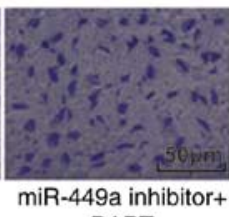

DAPT

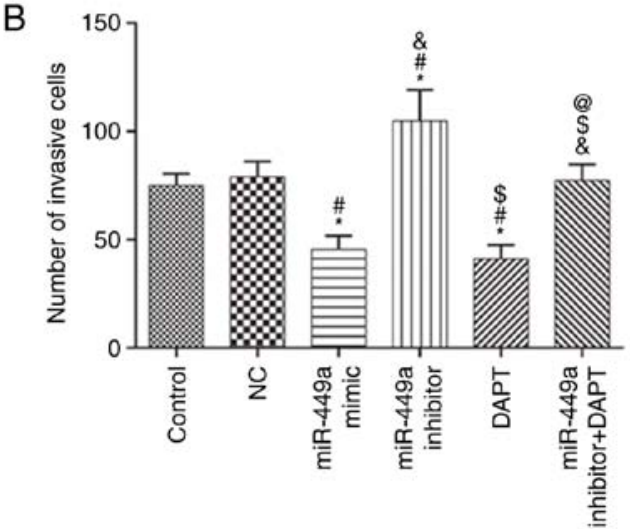

Figure 7. Cell invasion detection by Transwell assay (A) Cell invasion detection by Transwell assay (x200). (B) Number of invasive cells. * $\mathrm{P}<0.05$, compared with the control group; ${ }^{\#} \mathrm{P}<0.05$, compared with the NC group; ${ }^{\circledR} \mathrm{P}<0.05$, compared with the miR-449a mimic group; ${ }^{\$} \mathrm{P}<0.05$, compared with the miR-449a inhibitor group; ${ }^{\circledR} \mathrm{P}<0.05$, compared with the DAPT group. $\mathrm{NC}$, negative control.

DAPT group (both $\mathrm{P}<0.05$ ), and significantly decreased in the miR-449a inhibitor group $(\mathrm{P}<0.05)$.

Cell invasion. Cell invasion was detected by Transwell assay (Fig. 7). Compared with the control group, there was no significant difference in the number of invasive cells in the NC group and the miR-449a inhibitor + DAPT group (both $\mathrm{P}>0.05$ ); the number of invasive cells was significantly decreased in the miR-449a mimic group and DAPT group (both $\mathrm{P}<0.05$ ), and significantly increased in the miR-449a inhibitor group $(\mathrm{P}<0.05)$. Compared with the miR-449a inhibitor group, the number of invasive cells was significantly decreased in the miR-449a inhibitor + DAPT group $(\mathrm{P}<0.05)$.

mRNA expression of PCNA, MMP-2, MMP-9, Bcl-2 and Bax. The mRNA expression of proliferation-related factor PCNA, invasion-related factors MMP-2, MMP-9 and apoptosis-related factors Bcl-2 and Bax were detected by qRT-PCR (Fig. 8). Compared with the control group, there was no significant difference in the expression of these genes in the $\mathrm{NC}$ group and the miR-449a inhibitor + DAPT group (all P>0.05), however, there was a significant decrease in the mRNA expression of PCNA, MMP-2, MMP-9 and Bcl-2 and an increase of Bax mRNA expression in the miR-449a mimic group and DAPT group (all $\mathrm{P}<0.05$ ). In addition, there was a significant increase in the mRNA expression of PCNA, MMP-2, MMP-9 and Bcl-2 and a decrease of Bax mRNA expression in the miR-449a inhibitor group (all $\mathrm{P}<0.05$ ). Compared with the miR-449a inhibitor group, there was a significant decrease in the mRNA expression of PCNA, MMP-2, MMP-9 and Bcl-2 and increase of Bax mRNA expression in miR-449a inhibitor + DAPT group (all $\mathrm{P}<0.05$ ).

Protein expression of PCNA, MMP-2, MMP-9, Bcl-2 and Bax. The results of the western blotting are presented in Fig. 9. Compared with the control group, there was no significant

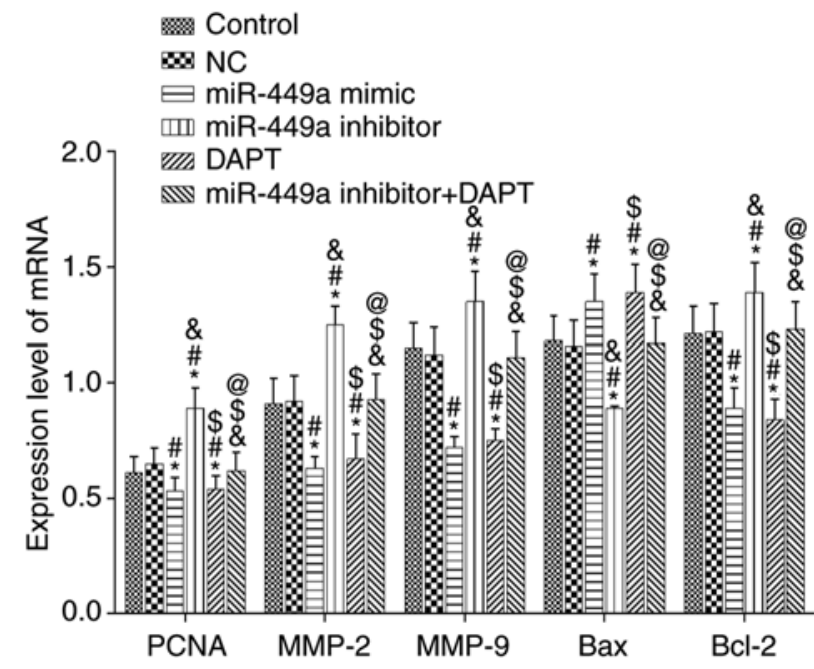

Figure 8. PCNA, MMP-2, MMP-9, Bax and Bcl-2 mRNA expression detection by qRT-PCR. ${ }^{*} \mathrm{P}<0.05$, compared with the control group; ${ }^{\text {"P }} \mathrm{P}<0.05$, compared with the NC group; ${ }^{\&} \mathrm{P}<0.05$, compared with the miR-449a mimic group; ${ }^{\$} \mathrm{P}<0.05$, compared with the miR-449a inhibitor group; ${ }^{\circledR} \mathrm{P}<0.05$, compared with the DAPT group. NC, negative control.

difference in the expression of these proteins in the $\mathrm{NC}$ group and miR-449a inhibitor + DAPT group (all P>0.05), however, there was a significant decrease in the protein expression of PCNA, MMP-2, MMP-9 and Bcl-2 and an increase of Bax protein expression in the miR-449a mimic group and DAPT group (all $\mathrm{P}<0.05)$. In addition, there was a significant increase in the protein expression of PCNA, MMP-2, MMP-9 and Bcl-2 and a decrease of Bax protein expression in the miR-449a inhibitor group (all $\mathrm{P}<0.05)$. Compared with the miR-449a inhibitor group, there was a significant decrease in the protein expression of PCNA, MMP-2, MMP-9 and Bcl-2 and an increase of Bax protein expression in the miR-449a inhibitor + DAPT group (all $\mathrm{P}<0.05)$. 

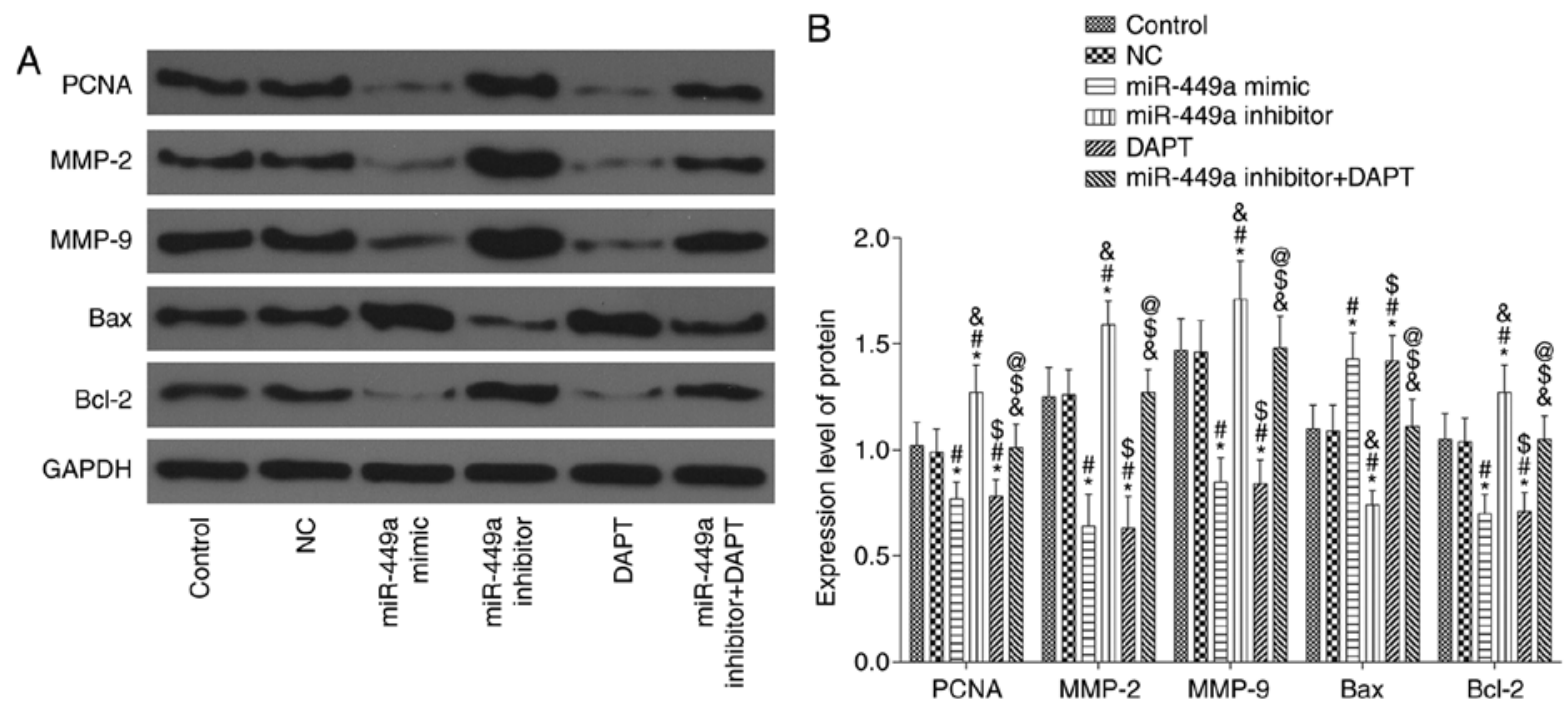

Figure 9. PCNA, MMP-2, MMP-9, Bax and Bcl-2 protein expression. (A) Protein bands. (B) PCNA, MMP-2, MMP-9, Bax and Bcl-2 protein expression. ${ }^{*} \mathrm{P}<0.05$, compared with the control group; ${ }^{*} \mathrm{P}<0.05$, compared with the $\mathrm{NC}$ group; ${ }^{\&} \mathrm{P}<0.05$, compared with the miR-449a mimic group; ${ }^{\$} \mathrm{P}<0.05$, compared with the miR-449a inhibitor group; ${ }^{\circledR} \mathrm{P}<0.05$, compared with the DAPT group. $\mathrm{NC}$, negative control.

\section{Discussion}

Thyroid carcinoma is one of the most common malignant tumors in the head and neck, and PTC is the most common cancer among thyroid carcinomas, accounting for about $80 \%$. The latest clinical data indicate that the incidence rate of thyroid carcinoma is on the rise worldwide (18). PTC has been revealed to be accompanied by distant lymphatic metastasis when diagnosed, due to the strong invasive ability of PTC cells and unapparent symptoms at the early stage. It is hard to trace the pathogenesis of PTC. Therefore, it is urgent to explore the molecular mechanism in the development of PTC and to develop broad-spectrum molecular targets and therapeutic drugs.

The downregulation of miR-449 has been observed in various human malignant tumors including lung cancer (19), gastric cancer (20) and colon cancer stem cells (21). The Notch receptor is a decisive factor of cell fate during the process of normal cell development $(22,23)$. The Notch signaling pathway as an important mechanism determining cell fate plays a vital role in the regulation of cell differentiation and development (21). The Notch signaling pathway also plays an important role in cell proliferation and apoptosis (24-26). Aberrantly high-expression of Notch receptor and its ligands in cancer cells has been confirmed in various cancers $(27,28)$.

It has been confirmed in some literature that Notch1 expression is increased in PTC and can promote downstream Jagged1 expression by activating the Notch signaling pathway, affecting the apoptosis, proliferation and invasion of PTC cells (29). In the present study, the Notch signaling pathway inhibitor DAPT was used to treat thyroid carcinoma cells TPC-1. It was revealed that there was significantly decreased expression of Notch1 and Jagged1, proliferation-related factor PCNA, invasion-related factors MMP-2, MMP-9 and apoptosis inhibitor Bcl-2 expression in cells, increased expression of apoptosis promoter Bax, decreased cell proliferation, blocked cell cycle progression, an increased apoptosis rate, and decreased cell invasion. The results revealed that the inhibition of the Notch signaling pathway suppressed the proliferation and invasion of PTC cells and promoted their apoptosis, which was consistent with previous research. To further explore the regulatory mechanism of the upstream Notch signaling pathway, it was predicted through a bioinformatics prediction website that there was a target relationship between Notch1 and miR-449. A previous study also indicated that miR-449 had an inhibitory effect on a variety of cancers (30). By dual-luciferase reporter assay, the negative regulation of miR-449 on Notch1 was also confirmed. TPC-1 cells were transfected with miR-449 mimic, miR-449 inhibitor and miR-449 inhibitor + DAPT, and the results revealed that miR-449 overexpression inhibited the proliferation and invasion of PTC cells and promoted their apoptosis. miR-449 inhibited the Notch signaling pathway by targetedly inhibiting Notch1 expression, which downregulated Jagged1 expression, inhibited the proliferation and invasion of PTC cells, and promoted their apoptosis. Moreover, the inhibition of the Notch signaling pathway recovered the promotion of PTC progression induced by miR-449 silencing. In the present study, the downregulation of miR-449 expression was detected in TPC-1 cells.

In the present study, it was confirmed that miR-449a mediated the Notch signaling pathway by targeting Notch1 to inhibit PTC progression. The underlying mechanism of PTC was further elucidated, which established the theoretical basis for PTC treatment in clinical practice. In addition, mice experiments are required to verify the aforementioned results. However, the relationship between miR-449a and PTC, the molecular mechanism of the miR-449a downstream Notch1 gene which affects PTC, and the targeted regulatory network of miR-449a in PTC are not entirely clear yet.

\section{Acknowledgements}

Not applicable.

\section{Funding}

The present study was supported by the Affiliated Hospital of Guilin Medical University (no. 20170109-7). 


\section{Availability of data and materials}

The analysed data sets generated during the study are available from the corresponding author on reasonable request.

\section{Authors' contributions}

YH contributed to all the tasks, including data collection, data analysis, experimental operation, manuscript design and writing. FF and RY made substantial contributions to the revision of the manuscript, the design of the study, and interpretation of data for this study. All authors provided final approval of the version to be published.

\section{Ethics approval and consent to participate}

Not applicable.

\section{Patient consent for publication}

Not applicable.

\section{Competing interests}

The authors declare that they have no competing interests.

\section{References}

1. Li Z, Huang X, Xu J, Su Q, Zhao J and Ma J: miR-449 overexpression inhibits papillary thyroid carcinoma cell growth by targeting RET kinase- $\beta$-catenin signaling pathway. Int J Oncol 49: 1629-1637, 2016.

2. Wu D, Liu J, Chen J, He H, Ma H and Lv X: miR-449a suppresses tumor growth, migration, and invasion in non-small cell lung cancer by targeting a HMGB1-Mediated NF- $\kappa \mathrm{B}$ signaling pathway. Oncol Res 27: 227-235, 2019.

3. Zhang YL, Li XB, Hou YX, Fang NZ, You JC and Zhou QH: The lncRNA XIST exhibits oncogenic properties via regulation of miR-449a and Bcl-2 in human non-small cell lung. Acta Pharmacol Sin 38: 371-381, 2017.

4. Ji C, Xu Q, Guo L, Wang X, Ren Y, Zhang H, Zhu W, Ming Z, Yuan Y, Ren X, et al: eEF-2 Kinase-targeted miR-449b confers radiation sensitivity to cancer cells. Cancer Lett 418: 64-74, 2018.

5. Zhang H, Cai Y, Zheng L, Zhang Z, Lin X and Jiang N: Long noncoding RNA NEAT1 regulate papillary thyroid cancer progression by modulating miR-129-5p/KLK7 expression. J Cell Physiol 233: 6638-6648, 2018.

6. Geraldo MV, Fuziwara CS, Friguglieti CU, Costa RB, Kulcsar MA, Yamashita AS and Kimura ET: MicroRNAs miR-146-5p and let-7f as prognostic tools for aggressive papillary thyroid carcinoma: A case report. Arq Bras Endocrinol Metabol 56: 552-557, 2012.

7. Bou Kheir T, Futoma-Kazmierczak E, Jacobsen A, Krogh A, Bardram L, Hother C, Grønbaek K, Federspiel B, Lund AH and Friis-Hansen L: miR-449 inhibits cell proliferation and is down-regulated in gastric cancer. Mol Cancer 10: 29, 2011.

8. Kim HJ, Kim MJ, Kim A, Jung CW, Park S, Koh JS and Myung JK: The role of notch1 signaling in anaplastic thyroid carcinoma. Cancer Res Treat 49: 509-517, 2017.

9. Cao YW, Wan GX, Sun JP, Cui XB, Hu JM, Liang WH, Zheng YQ, Li WQ and Li F: Implications of the Notch1-Snail/Slug-epithelial to mesenchymal transition axis for lymph node metastasis in infiltrating ductal carcinoma. Kaohsiung J Med Sci 31: 70-76, 2015.

10. Gopalakrishnan N, Sivasithamparam ND and Devaraj $\mathrm{H}$ Synergistic association of Notch and NFKB signaling and role of Notch signaling in modulating epithelial to mesenchymal transition in colorectal adenocarcinoma. Biochimie 107: 310-318, 2014.

11. Wang Z, Li Y, Kong D and Sarkar FH: The role of Notch signaling pathway in epithelial-mesenchymal transition (EMT) during development and tumor aggressiveness. Curr Drug Targets 11: 745-751, 2010.
12. Bao B, Wang Z, Ali S, Kong D, Li Y, Ahmad A, Banerjee S, Azmi AS, Miele L and Sarkar FH: Notch-1 induces epithelial-mesenchymal transition consistent with cancer stem cell phenotype in pancreatic cancer cells. Cancer Lett 307: 26-36, 2011.

13. Hu KF, Kong XY, Zhong MC, Wan HY, Lin N and Pei XH: Brucine inhibits bone metastasis of breast cancer cells by suppressing Jagged1/Notch1 signaling pathways. Chin J Integr Med 23: 110-116, 2017.

14. Yang Q, Cao X, Tao G, Zhou F, Zhao P, Shen Y and Chen X: Effects of FOXJ2 on TGF-beta1-induced epithelial-mesenchymal transition through Notch signaling pathway in non-small lung cancer. Cell Biol Int 41: 79-83, 2017.

15. Bi YL, Min M, Shen W and Liu Y: Numb/Notch signaling pathway modulation enhances human pancreatic cancer cell radiosensitivity. Tumour Biol 37: 15145-15155, 2016.

16. Cheng J, Wu Q, Lv R, Huang L, Xu B, Wang X, Chen A and He F: MicroRNA-449a inhibition protects H9C2 cells against hypoxia/reoxygenation-induced injury by targeting the Notch-1 signaling pathway. Cell Physiol Biochem 46: 2587-2600, 2018.

17. Livak $\mathrm{K}$ and Schmittgen T: Analysis of relative gene expression data using real-time quantitative PCR and the 2(-Delta Delta C(T)) method. Methods 25: 402-408, 2001.

18. Hu J, Li C, Liu C, Zhao S, Wang Y and Fu Z: Expressions of miRNAs in papillary thyroid carcinoma and their associations with the clinical characteristics of PTC. Cancer Biomark 18: 87-94, 2017.

19. Luo W, Huang B, Li Z, Li H, Sun L, Zhang Q, Qiu X and Wang E: MicroRNA-449a is downregulated in non-small cell lung cancer and inhibits migration and invasion by targeting c-Met. PLoS One 8: e64759, 2013.

20. Yang X, Wang HL, Liang HW, Liang L, Wen DY, Zhang R, Chen $G$ and Wei DM: Clinical significance of microRNA-449a in hepatocellular carcinoma with microarray data mining together with initial bioinformatics analysis. Exp Ther Med 15: 3247-3258, 2018.

21. Li F, Liang J and Bai L: MicroRNA-449a functions as a tumor suppressor in pancreatic cancer by the epigenetic regulation of ATDC expression. Biomed Pharmacother 103: 782-789, 2018.

22. Aster JC, Pear WS and Blacklow SC: The varied roles of notch in cancer. Annu Rev Pathol 12: 245-275, 2017.

23. Rong C, Feng Y and Ye Z: Notch is a critical regulator in cervical cancer by regulating Numb splicing. Oncol Lett 13: 2465-2470, 2017.

24. Yang X, Duan B and Zhou X: Long non-coding RNA FOXD2-AS1 functions as a tumor promoter in colorectal cancer by regulating EMT and Notch signaling pathway. Eur Rev Med Pharmacol Sci 21: 3586-3591, 2017.

25. Zhou Y, An Q, Guo RX, Qiao YH, Li LX, Zhang XY and Zhao XL: miR424-5p functions as an anti-oncogene in cervical cancer cell growth by targeting KDM5B via the Notch signaling pathway. Life Sci 171: 9-15, 2017.

26. Shen Q, Cohen B, Zheng W, Rahbar R, Martin B, Murakami K, Lamorte S, Thompson P, Berman H, Zúñiga-Pflücker JC, et al: Notch shapes the innate immunophenotype in breast cancer. Cancer Discov 7: 1320-1335, 2017.

27. Li C, Liu S, Yan R, Han N, Wong KK and Li L: CD54-NOTCH1 axis controls tumor initiation and cancer stem cell functions in human prostate cancer. Theranostics 7: 67-80, 2017.

28. Cai H, Yao J, An Y, Chen X, Chen W, Wu D, Luo B, Yang Y, Jiang Y, Sun D and He X: LncRNA HOTAIR acts a competing endogenous RNA to control the expression of notch 3 via sponging miR-613 in pancreatic cancer. Oncotarget 8: 32905-32917, 2017.

29. Jung CW, Kong JS, Seol H, Park S, Koh JS, Lee SS, Kim MJ, Choi IJ and Myung JK: Expression of activated Notch1 and Hey1 in papillary thyroid carcinoma. Histopathology 70: 301-308, 2017.

30. Sun J, Shi R, Zhao S, Li X, Lu S, Bu H, Ma X and Su C: E2F8, a direct target of miR-144, promotes papillary thyroid cancer progression via regulating cell cycle. J Exp Clin Cancer Res 36: 40, 2017. 